Journal of Advanced Research in Fluid Mechanics and Thermal Sciences

Journal homepage: www.akademiabaru.com/arfmts.html ISSN: 2289-7879

\title{
Feasibility Study of using Oil Palm Trunk Waste Fiber as Fluid Loss Control Agent and Lost Circulation Material in Drilling Mud
}

\begin{abstract}
Arina Sauki ${ }^{1}{ }^{*}$, Muhammad Saifudin Mohd Azmi ${ }^{1}$, Husna Hayati Jarni ${ }^{1}$, Wan Zairani Wan Bakar ${ }^{1}$, Tengku Amran Tengku Mohd ${ }^{1}$, Nik Khairul Irfan Nik Ab. Lah ${ }^{1}$, Putri Nadzrul Faizura Megat Khamaruddin ${ }^{1}$, Wan Asma Ibrahim ${ }^{2}$
\end{abstract}

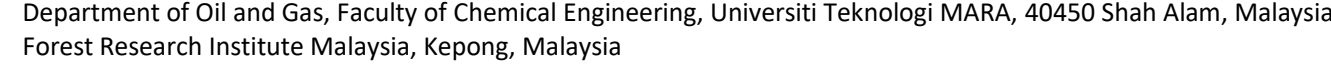

ARTICLE INFO

\section{Article history:}

Received 24 December 2019

Received in revised form 7 April 2020

Accepted 8 April 2020

Available online 8 June 2020

Keywords:

API filtration test; drilling mud; filter cake thickness; fluid lost control; lost circulation material; oil palm trunk fiber; sand bed test

\section{ABSTRACT}

An investigation was conducted on Oil Palm Trunk (OPT) fiber that was used as fluid loss control (FLC) agent and lost circulation material (LCM) in drilling fluid. API filtration test was performed to evaluate the performance of OPT fiber as FLC while sand bed test was performed to evaluate the performance of OPT fiber as LCM. For the API filtration test, the addition of OPT fiber reduced the fluid loss while the filter cake thickness increased as higher amount of OPT fiber was added into the drilling mud. The use of fine size OPT fiber $(<75 \mu \mathrm{m})$ yielded the lowest fluid loss volume. For the sand bed test, mud invasion reduced as the concentration of OPT fiber increased. The findings also revealed that the OPT fiber with the size of 75-150 $\mu \mathrm{m}$ performed best in reducing mud invasion with the value of merely $1 \mathrm{~cm}$. Thus, it can be concluded that OPT fiber has a high potential to be used as FLC and LCM in drilling mud.

\section{Introduction}

Fluid loss is the result of filtrate loss from drilling fluid into the formation. Invasion of filtrate into formation could reduce the permeability near the wellbore zone that can lead to lower production. If the filtrate invades the shale section, it can cause the clay swelling that can lead to pipe sticking [1]. Therefore, FLC is added to the drilling fluid to prevent or reduce the fluid loss. According to Navarrete et al., [2], there were two basic mechanisms in which fluid loss control can be achieved. First mechanism, fluid loss control can be achieved by increasing the overall viscosity of the drilling

\footnotetext{
* Corresponding author.

E-mail address: arina_sauki@uitm.edu.my (Arina Sauki)
}

https://doi.org/10.37934/arfmts.72.1.920 
fluid using water-dispersible polymers such as carboxymethyl cellulose (CMC), polyanionic cellulose (PAC), hyrdroxyethyl cellulose (HEC). The use of water dispersible polymers has direct impact to drilling mud bulk viscosity. Second mechanism is fluid loss control can be achieved by forming internal or external filter cake to plug the formation pore throats using insoluble material such as calcium carbonate and unmodified cellulosic fiber. According to [3], modification is necessary for natural cellulosic fiber to be used as FLC. This is because natural cellulose is insoluble in water. However, several researchers have proved that the use of unmodified cellulosic fiber could achieve the fluid loss control in about 1 to $7 \mathrm{ml}$ depending on the type, concentration and size of the natural FLC (Azlinda Azizi et al., 2013; N. A. Ghazali et al., 2014; Alsabagh et al., 2015; Ramasamy and Amanullah 2017; Nurul Aimi Ghazali, Yusof, et al., 2015). According to [4-6], small and fine particles of insoluble fibers are capable to fill the pore spaces between the filter cake. Therefore, fluid loss can be reduced. Thus, it can be concluded that the use of unmodified cellulosic fiber could also achieve the fluid loss control through the second mechanism. Since the control is achieved physically, it is expected the filter cake thickness will increase as more raw material is used to reduce the fluid loss. Study by [7-9] shows that as the higher amount of raw material used to reduce the fluid loss, the thickness of filter cake increased.

Loss circulation can be defined as total or partial loss of drilling fluid into the formation $[10,11]$. Mud losses into formation have economic impact and cause drilling problems. Mud is accountable for 25 to $40 \%$ of total drilling cost [12]. Non- productive time was spent to cure the lost circulation. Lost circulation also leads to poor hole cleaning, increase formation damage and pore plugging [12]. Severe mud losses will lead to well control problems. Total loss of drilling fluid occurred when there was no mud returning to the surface. Partial lost circulation is when volume of mud returned to the surface is less than the volume of mud pumped into the well [10]. In order to cure or prevent lost circulation or mud loss during drilling, lost circulation materials (LCM) can be used in the drilling fluids. There are four types of LCM, which is fibrous materials, flaky materials, granular materials and hydrated slurries [3]. LCM also can be divided into two types which is particulates LCMs and fibrous [12]. Particulates LCMs include granular and flaky materials. Amongst the example of fibrous materials are micronized cellulose, bagasse, sawdust, wood fibers, shredded tyres and paper pulp [3]. Fiber materials are the materials with less rigidity unlike granular materials. The working principle of LCM is simple. As the LCM has been transported to the fractures, the coarse LCM will bridge the fractures to provide the mechanical strength. In case of fiber, it will create the network structure across the fracture. Subsequent seal will be provided by deposition of small particles on top of the bridged or network created. Small particles are attributed to fine LCM or fine clay in the drilling fluid [12].

In this study, Oil Palm Trunk Fiber was used to investigate its potential as fluid loss control (FLC) additive as well as loss circulation material (LCM). Oil palm biomass (OPB) can be classified as lignocellulosic wastes [13]. Oil palm industries produce at least 30 million tonnes of OPB per annum [14]. According to [15], OPB can be classified into six types which are oil palm fronds (OPF), oil palm trunks (OPT), empty fruit bunches (EFB), palm kernel shells (PKS), mesocarp fiber (MF) and palm oil mill effluent (POME). The first two types of OPB are commonly produced at the plantation site while the rest were generated from the mill site. According to [16], oil palm-based plywood mills utilized $40 \%$ of OPT, the other $60 \%$ of OPT was discarded as waste or residue. The residue is classified as Oil Palm Trunk Waste (OPTW). The main components of oil palm biomass (OPB) fiber are holocellulose and lignin which are about $70 \%-80 \%$ and $17 \%-25 \%$ respectively [15]. Free hydroxyl cellulose has strong attraction to solvents and solution such as water and the moisture sorption process is achieved through hydrogen bond [17]. Thus, it is expected that OPT fiber can retain water in drilling mud 
through its lignocellulosic properties and reducing fluid loss. In addition, OPT fiber can be categorized as fibrous LCM.

\section{Methodology}

\subsection{Preparation of Oil Palm Trunk Fiber}

OPT Waste Fiber was obtained from Forest Research Institute Malaysia (FRIM) located at Kepong. The OPT was originated from the core part of the Oil Palm Trunk. The OPT was milled into a size of about $1 \mathrm{~cm}$ using milling machine owned by FRIM prior to collection. Then, the OPT was oven dried at $70^{\circ} \mathrm{C}$ for 24 hours. The dried OPT fiber was ground into smaller sizes as shown in Table 1.

Table1

\begin{tabular}{ll} 
Classification of ground OPT fiber \\
\hline Classification of sizes & Range of sizes \\
\hline Fine & $<75 \mu \mathrm{m}$ \\
Medium & 75 to $150 \mu \mathrm{m}$ \\
Medium & 150 to $250 \mu \mathrm{m}$ \\
Intermediate & 250 to $350 \mu \mathrm{m}$ \\
Intermediate & 350 to $500 \mu \mathrm{m}$ \\
\hline
\end{tabular}

\subsection{Preparation of Mud Samples}

The materials used to formulate water base mud was formulated using materials obtained from Scomi Oil Tools Sdn Bhd located at Bukit Jelutong, Shah Alam. The materials were mixed using Hamilton Beach Mixer for 45 minutes. The polymer-based mud system was formulated using water, soda ash, potassium chloride, starch, xanthan gum, $\mathrm{NaOH}$ and barite. The OPT fibers were added in the base mud at different sizes and concentrations as shown in Table 2.

\section{Table 2}

Mud samples composition

\begin{tabular}{|c|c|}
\hline Sample & Sample's composition \\
\hline \multicolumn{2}{|c|}{ Filtration Test } \\
\hline A & Base Mud \\
\hline B & Base Mud+ $4 \mathrm{~g}<75 \mu \mathrm{m}$ of OPT fiber \\
\hline C & Base Mud $+4 \mathrm{~g} 75$ to $150 \mu \mathrm{m}$ of OPT fiber \\
\hline $\mathrm{C} 1$ & Base Mud+ $2 \mathrm{~g} 75$ to $150 \mu \mathrm{m}$ of OPT fiber \\
\hline $\mathrm{C} 2$ & Base Mud+ $6 \mathrm{~g} 75$ to $150 \mu \mathrm{m}$ of OPT fiber \\
\hline $\mathrm{D}$ & Base Mud+ 4g 150 to $250 \mu \mathrm{m}$ of OPT fiber \\
\hline$E$ & Base Mud+ 4g 250 to $350 \mu \mathrm{m}$ of OPT fiber \\
\hline $\mathrm{F}$ & Base Mud+ 4g 350 to $500 \mu \mathrm{m}$ of OPT fiber \\
\hline \multicolumn{2}{|c|}{ Sand Bed Test } \\
\hline A & Base Mud \\
\hline G & Base Mud $+6 \%<75 \mu \mathrm{m}$ of OPT fiber $(\approx 6.49 \mathrm{~g})$ \\
\hline G1 & Base Mud $+2 \%<75 \mu \mathrm{m}$ of OPT fiber $(\approx 2.17 \mathrm{~g})$ \\
\hline G2 & Base Mud $+10 \%<75 \mu \mathrm{m}$ of OPT fiber $(\approx 10.83 \mathrm{~g})$ \\
\hline $\mathrm{H}$ & Base Mud $+6 \% 75$ to $150 \mu \mathrm{m}$ of OPT fiber $(\approx 6.49 \mathrm{~g})$ \\
\hline I & Base Mud $+6 \% 150$ to $250 \mu \mathrm{m}$ of OPT fiber $(\approx 6.49 \mathrm{~g})$ \\
\hline $\mathrm{J}$ & Base Mud $+6 \% 250$ to $350 \mu \mathrm{m}$ of OPT fiber $(\approx 6.49 \mathrm{~g})$ \\
\hline K & Base Mud $+6 \% 350$ to $500 \mu \mathrm{m}$ of OPT fiber $(\approx 6.49 \mathrm{~g})$ \\
\hline
\end{tabular}




\subsection{Rheological Test}

Rheological test of the drilling fluid was conducted using Fann Viscometer 35SA according to API Recommended Practice 13B-1 [18,19]. The rheological properties of drilling fluid were tested at $120^{\circ} \mathrm{F}$ using the cup that connected to water bath. The test was run at $600,300,200,100,6$ and 3 rpm.

Calculation

Plastic Viscosity, PV expressed in cP

$P V=R_{600}-R_{300}$

Yield Point, YP expressed in $\mathrm{lb} / 100 \mathrm{ft}^{2}$

$\mathrm{YP}=\mathrm{R}_{300}-\mathrm{PV}$

where $R_{600}=$ dial reading at $600 \mathrm{rpm}, \mathrm{R}_{300}=$ dial reading at $300 \mathrm{rpm}$

For the determination of gel strength, the drilling fluid was stirred at $600 \mathrm{rpm}$ for 30 seconds. After that, drilling fluid was allowed to be undisturbed for 10 seconds (for the determination of gel strength after 10 seconds). After 10 seconds, the viscometer was run at the rotor speed of $3 \mathrm{rpm}$. The maximum reading after starting the rotation at $3 \mathrm{rpm}$ was taken and recorded in $\mathrm{lb} / 100 \mathrm{ft}^{2}$. The same steps were repeated to determine gel strength for 10 minutes.

\subsection{API Filtration Test}

Filtration test for mud samples A to F was conducted according to API Recommended Practice 13B-1 [18]. The filtration test was conducted at 100 psi for 30 minutes. After 30 minutes, the filtrate volume was collected and measured using measuring cylinder. The filter cake thickness was also measured in $\mathrm{mm}$ unit using digital vernier caliper. The filtrate volume collected must be less than 15 $\mathrm{ml}[20,21]$. The good filter cake thickness should be less than $2 / 32$ inch $(\approx 1.6 \mathrm{~mm})$ or $2 \mathrm{~mm}[1,22]$.

\subsection{Sand Bed Test}

Sand bed test was conducted for mud samples A, G1 to K. The procedure for conducting sand bed test was done based on $[23,24]$. The sand bed test was conducted by using modified LPLT filter press with clear Plexiglas cylinder. The test was conducted at 100 psi for 30 minutes. After 30 minutes, depth of mud invasion into sand bed was measured. 20/40 frac sand was used as sand bed to simulate formation porosity and permeability. The mud invasion below $5 \mathrm{~cm}$ shows the good performance of LCM [4].

\section{Results and Discussion}

\subsection{The Effect of OPT Fiber Amount to the Rheological Properties of Mud}

As the intent of this invent is to determine the feasibility of oil palm trunk waste (OPT) fiber to be used as fluid loss control additive or lost circulation additive, the rheological test was conducted in order to identify whether this material can give an adverse effect to the mud rheology or vice versa. 
For this material to be applied in the drilling fluid, it should not adversely affect the rheology or increase the ECD [25]. Table 3 shows the rheology readings of mud samples at different amount of OPT fiber. It could be observed that the addition of OPT fiber at different amount can only cause a slight increase in plastic viscosity from $15 \mathrm{cP}$ to a maximum of $20 \mathrm{cP}$ which is equivalent to about $33.3 \%$ of PV increment. This value is considered reasonable as compared to other studies by previous researchers. A study by [26] found that the addition of different cellulosic fibers such as peanut hull, sawdust and bagasse into drilling fluid have increased the plastic viscosity from $3 \mathrm{cP}$ to $5 \mathrm{cP}$ at maximum which is equivalent to $66 \%$ of PV increment. On the other note, N.A. Ghazali et. al [1] found that the addition of corn starch at $2 \mathrm{~g}, 4 \mathrm{~g}, 6 \mathrm{~g}, 8 \mathrm{~g}$ and $10 \mathrm{~g}$ caused the plastic viscosity to increase from $2.67 \mathrm{cP}$ to $5 \mathrm{cP}$ that approximately $87.3 \%$ of PV increment. Meanwhile, N.A. Ghazali et. al [8] have found that addition of apple skin powder at $7.5 \mathrm{~g}, 12.5 \mathrm{~g}$ and $17.5 \mathrm{~g}$ into drilling fluid caused the plastic viscosity to increase from $28 \mathrm{cP}$ to 34,30 and $31 \mathrm{cP}$ respectively that is approximately $21.42 \%$ increment by maximum. In overall, PV increment of unmodified natural fibers addition into drilling fluid were found to fall within $21-87 \%$. It is suggested that an engineered approach should be taken in later study to modify the fiber so that it can minimally affect the mud rheology in order to achieve full benefit of the fluid loss or LCM additive. Other rheological properties such as yield point (YP) and gel strength (GS) show that the parameters increase at increasing amount of OPT fiber which is similar to the trend of PV.

Table 3

Rheological properties of mud at Different Amount of OPT fiber ( 75 to $150 \mu \mathrm{m}$ )

\begin{tabular}{|c|c|c|c|c|}
\hline & Base Mud & $2 g$ & $4 g$ & $6 g$ \\
\hline Mud sample & $\mathrm{A}$ & $\mathrm{C} 1$ & $\mathrm{C}$ & $\mathrm{C} 2$ \\
\hline $600 \mathrm{rpm}$ & 67 & 78 & 88 & 95 \\
\hline 300 rpm & 52 & 61 & 69 & 75 \\
\hline 200 rpm & 44 & 52 & 62 & 64 \\
\hline 100 rpm & 34 & 40 & 48 & 49 \\
\hline $6 \mathrm{rpm}$ & 15 & 18 & 22 & 21 \\
\hline $3 \mathrm{rpm}$ & 12 & 14 & 18 & 17 \\
\hline Plastic Viscosity, cP & 17 & 17 & 19 & 20 \\
\hline Yield Point, lb/100ft ${ }^{2}$ & 36 & 44 & 50 & 55 \\
\hline 10 seconds gel strength, Ib/100ft ${ }^{2}$ & 12 & 14 & 17 & 16 \\
\hline 10 minutes gel strength, $\mathrm{lb} / 100 \mathrm{ft}^{2}$ & 15 & 16 & 20 & 19 \\
\hline
\end{tabular}

\subsection{The Effect of OPT Fiber Amount to the Filtration Properties of Mud.}

Figure 1 shows the effect of increased amount of OPT fiber added in drilling mud to fluid loss. It could be observed that the filtrate loss was reduced as the higher amount of OPT fiber added to the drilling fluid. The addition of $2 \mathrm{~g}, 4 \mathrm{~g}$ and $6 \mathrm{~g}$ of 75 to $150 \mu \mathrm{m}$ of OPT fiber reduced the API fluid loss from $6.5 \mathrm{ml}$ to $5 \mathrm{ml}$. The results obtained were consistent with the findings from past researchers where the addition of cellulosic fiber into mud could reduce the fluid loss [9,26]. Alsabagh et al., [26] have observed the reduction of fluid loss from $100 \mathrm{ml}$ to $47 \mathrm{ml}, 38.8 \mathrm{ml}$ and $29 \mathrm{ml}$ by addition of $1.5 \%$, $3 \%$ and $6 \%$ of coarse peanut hulls respectively. In addition, Okon et al., [9] observed the similar trend where the addition of $5 \mathrm{~g}, 10 \mathrm{~g}, 15 \mathrm{~g}$, and $20 \mathrm{~g}$ of rice husk reduced the fluid loss from $47 \mathrm{ml}$ to $42.5 \mathrm{ml}$, $35 \mathrm{ml}$ and $24.5 \mathrm{ml}$ respectively. 


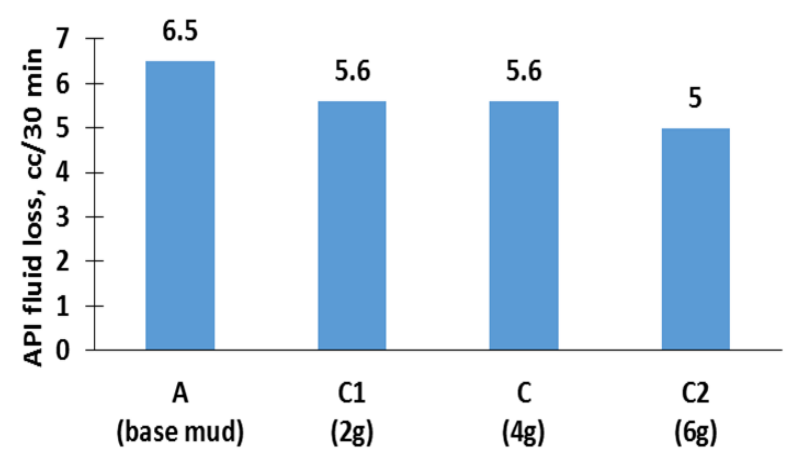

Fig. 1. Effect of increased amount of OPT fiber to filtration properties of drilling fluid

It can also be observed that the fluid loss reduced with the increasing amount of OPT fiber and filter cake's thickness as shown in Figure 2. As the fluid loss reduced from $6.5 \mathrm{ml}$ to $5 \mathrm{ml}$, the cake thickness increased from $0.5 \mathrm{~mm}$ to $0.79 \mathrm{~mm}$. These results show that the thicknesses of filter cakes are within the acceptable limit whereby the thickness should be below than $2 \mathrm{~mm}[1,27]$. Several other researchers have observed an increase trend of mud cake thickness at increase amount of LCM whereby Okon et al., [9] found that the addition of $10 \mathrm{~g}, 15 \mathrm{~g}$ and $20 \mathrm{~g}$ of rice husk to water based mud increased the cake thickness from $1 \mathrm{~mm}$ to $1.5 \mathrm{~mm}, 2.4 \mathrm{~mm}$ and $3.2 \mathrm{~mm}$ respectively. A study by Ramasamy \& Amanullah [7] found that addition from $10 \mathrm{ppb}$ to $30 \mathrm{ppb}$ of deceased date tree waste have increased the cake thickness from $12.7 \mathrm{~mm}, 14 \mathrm{~mm}, 13 \mathrm{~mm}$ and $12 \mathrm{~mm}$ to $29 \mathrm{~mm}, 21 \mathrm{~mm}, 19$ $\mathrm{mm}$ and $21 \mathrm{~mm}$ respectively.

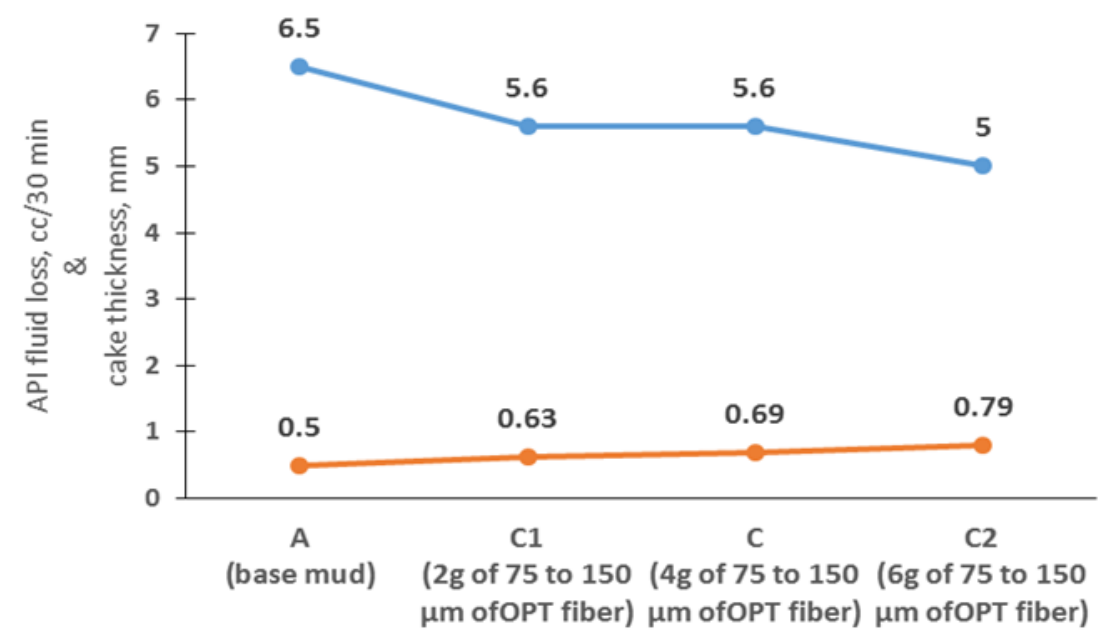

Fig. 2. Effect of OPT fiber amount to filter cake thickness (Note: The blue line refers to API fluid loss and the orange line refers to mud cake thickness)

\subsection{The Effect of Different Sizes of OPT Fiber to Filtration Properties.}

Figure 3 shows the effect of different sizes of OPT fiber added in drilling mud to fluid loss. It was observed that the use of smaller sizes of OPT fiber into drilling fluid reduced the fluid loss from 6.5 $\mathrm{ml}$ to $5.2 \mathrm{ml}$. Mud sample B that was formulated with the smallest OPT fiber size ( $<75$ micron) yielded the lowest fluid loss volume $(5.2 \mathrm{ml})$. This is because smaller particles is capable to fill the spaces 
between the filter cake better as compared to coarser particles during filtration process $[4,6,28]$.Therefore, fluid loss was reduced. Similar trends were also observed by several researchers. Ghazali et al., [29] observed that the addition of 150 micron, 250 micron and 500 micron of lemongrass to the water base mud resulting the fluid loss of $5 \mathrm{ml}, 5.3 \mathrm{ml}$ and $5.5 \mathrm{ml}$ respectively. Majid et al., [28] found that the addition of fine durian rind powder yielded in $4.1 \mathrm{ml}$ of fluid loss. While, the addition of coarse durian rind powder resulted in $11 \mathrm{ml}$ of fluid loss.

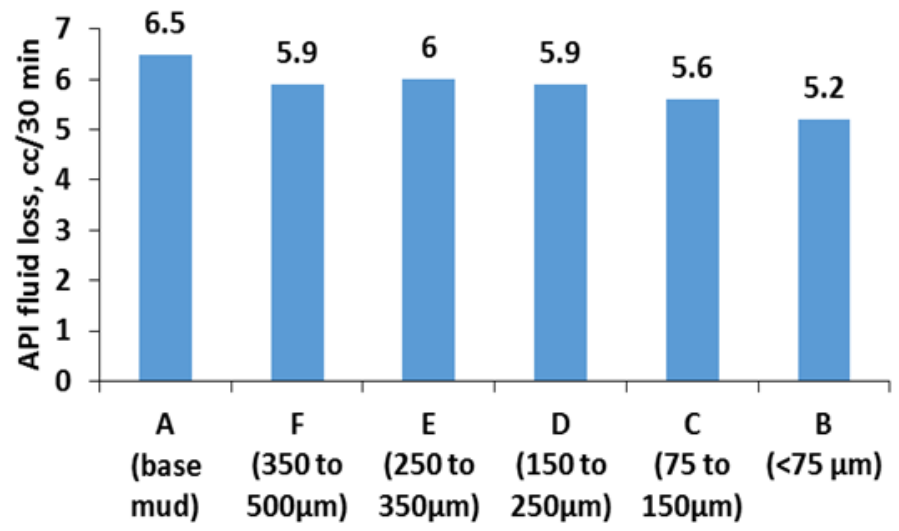

Fig. 3. Effect of different sizes of OPT fiber to filtration properties of drilling mud

Other than that, OPT fiber can act as FLC because it is comprised of cellulose and hemicellulose. Cellulose and hemicellulose absorb the water in drilling fluid. Therefore, the base fluid can be retained and prevented from loss of fluid into the formation. Cellulose and hemicellulose are hydrophilic and contains large amount of hydroxyl group. Therefore, it is possible that the moisture sorption process achieved through their hydrogen bonds [30]. Cellulose is classified as hygroscopic since it will absorb water and swell [31]. However, as we can observe from Figure 2 and 3, there was only small reduction of fluid loss took places. The addition of OPT fiber of $6 \mathrm{~g}$ could only reduce the fluid loss approximately by $23 \%$. This is maybe due to the presence of lignin in between cellulose and hemicellulose. The presence of lignin in between them cause disturbance for the absorption of water to take place. Lignin itself is hydrophobic therefore, it does not absorb water [31]. It also interferes the swelling and refining of the fiber. Lignin will react as encrusting agent for the cellulose and hemicellulose loose matrix and commonly referred as plant cell wall adhesive [32]. Hence, the surrounding and crosslinking of lignin between the polysaccharides-cellulose and hemicellulose in the cell wall, provide an obstacle for effective water/ moisture absorption process to take place.

\subsection{The Effect of Different Sizes of OPT Fiber to Mud Losses and Mud Invasion.}

Sand bed test was conducted with $6 \%$ of OPT fiber at different sizes. The purpose is to determine the suitable sizes of OPT fiber that can plug the pore spaces in between of 20/40 sand. According to [4], mud invasion of less than $5 \mathrm{~cm}$ is deemed as a good LCM performance. Based on Figure 4, it was observed that mud sample $A, J$ and $K$ have failed to prevent or reduce the mud losses. Other mud samples such as $G, H$, and I have successfully reduced the mud losses into formation as the reading shows below $5 \mathrm{~cm}$. For sample $A$, mud losses occur due to the base mud contained no bridging particles thus pore spaces between sand or formation were not plugged. According to [33], the median particle size of the bridging additive needs to be equal to or slightly greater than one-third the median pore size of the formation. Therefore, the expected suitable fiber size, which is one-third of $20 / 40$ sand was in the range of 100 to $300 \mu \mathrm{m}$. For the sample $\mathrm{G}, \mathrm{H}$ and I, the use of suitable sizes 
of OPT fiber enable the fiber to travel into the pore spaces. Mechanical bridge was formed, and finer particles were able to deposit on top of it. Therefore, low permeability seal was formed. Low permeability seal can reduce or prevent further mud losses and mud invasion into formation. Based on Figure 4, 75 to $100 \mu \mathrm{m}$ is the most suitable size for OPT fiber LCM since the mud sample $\mathrm{H}$ has the lowest mud invasion of $1.0 \mathrm{~cm}$.

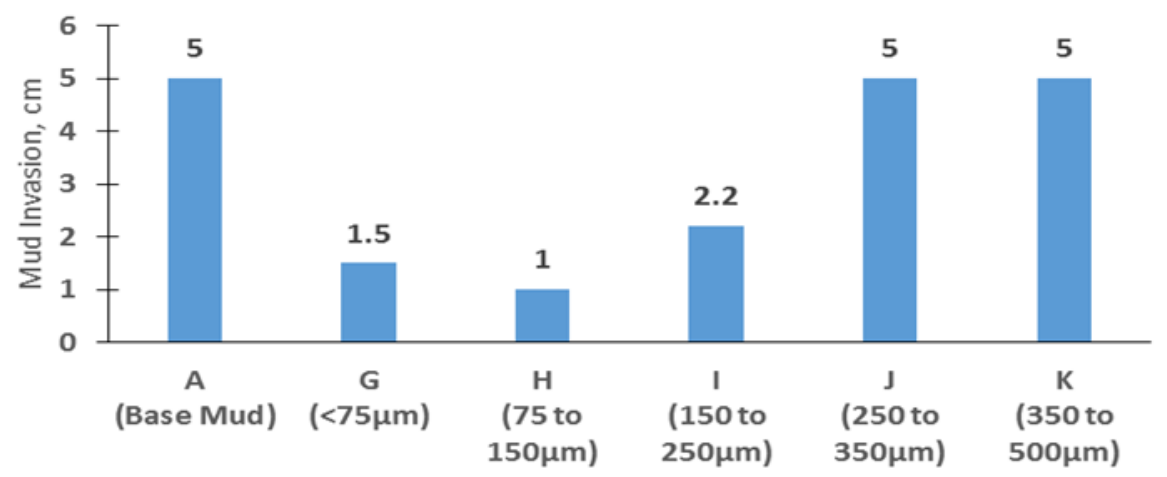

Fig. 4. Effect of different OPT fiber sizes to mud invasion

After the completion of sand bed test, the residual drilling fluid located on top of 20/40 sand bed was removed. Figure 5 shows a merely thin deposition of OPT fiber on top of sand bed for mud sample $\mathrm{H}$. It showed that most of the OPT fiber added to drilling mud have travelled into the pore spaces between sand bed to form bridge and seal. Instead, from Figure 6, a thick deposition of OPT fiber was observed for mud sample $K$. This is because the size of OPT fiber used in mud sample $K$ is too large and unsuitable for pore size of 20/40 sand bed. Therefore, most of the OPT fiber cannot invade and travelled into the pore spaces and deposited on top of the sand bed.

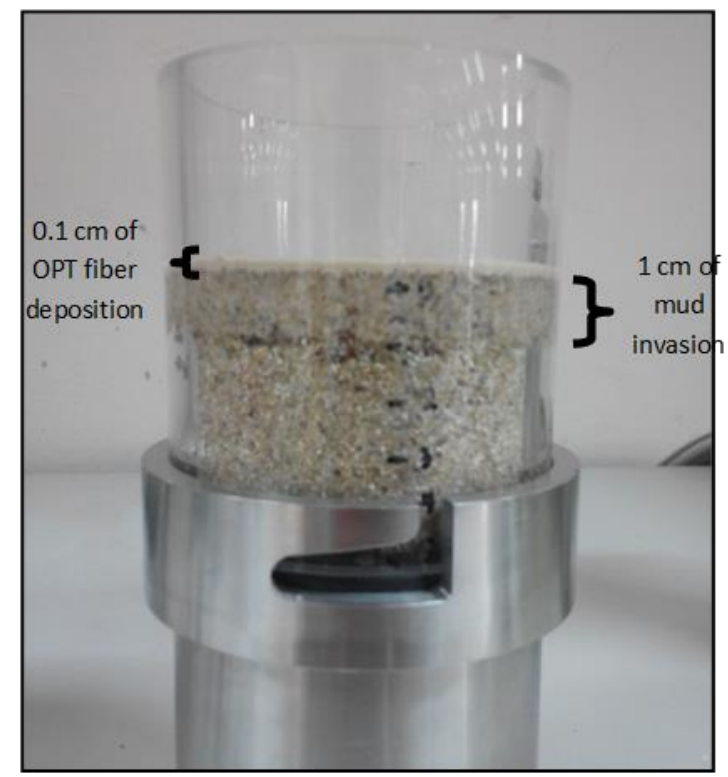

Fig. 5. Thin deposition of OPT fiber on top of sand bed for mud sample $\mathrm{H}$ 


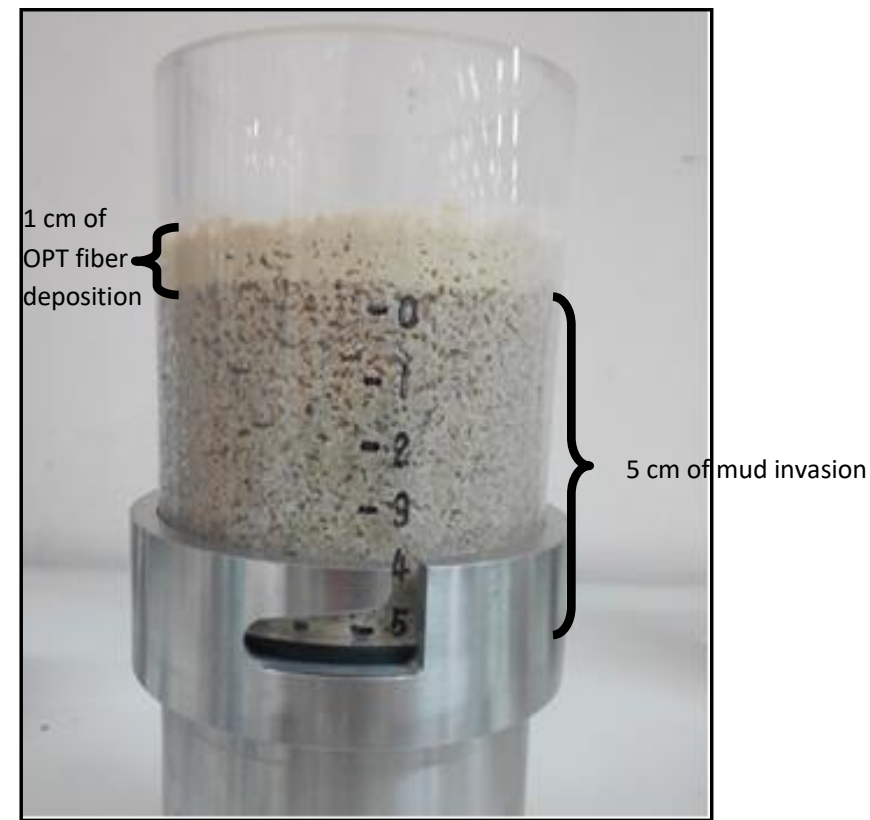

Fig. 6. Thick deposition of OPT fiber on top of sand bed for mud sample $\mathrm{K}$

\subsection{The Effect of Different Concentration of OPT Fiber to Mud Losses and Mud Invasion}

According to Abram's rule, the concentration of the bridging size solids must be at least 5 percent by volume of the solids in the final mud mix [33]. Figure 7 shows the result of the sand bed test conducted at increasing concentration of $<75 \mu \mathrm{m}$ OPT fiber. It can be observed that as the concentration of OPT fiber increased, the mud invasion losses into formation reduced. The mud samples $A$ and $\mathrm{G} 1$ having $5 \mathrm{~cm}$ mud invasion instantly at $0 \%$ and $2 \%$ of OPT. LCM performed poorly at this condition due to the concentration of OPT fiber used in the mud samples was less than $5 \%$. Sufficient amount of OPT fiber is needed to create the bridge [12]. Therefore, it can be concluded that $0 \%$ and $2 \%$ concentration of OPT fiber is insufficient to form a mechanical bridge and no permeability seal was created. On the other hand, it can be observed that mud sample $G$ and $G 2$ having $1.5 \mathrm{~cm}$ and $1.1 \mathrm{~cm}$ mud invasion respectively. It shows a good performance of LCM in combatting mud loss at $4 \%$ and $6 \%$ concentration of OPT fiber. Thus, it can be concluded for this experiment, $6 \%$ concentration of OPT fiber is the best concentration needed to form mechanical bridge and low permeability seal. The results obtained agreed to Abram's rule that stated the concentration of the bridging size solids must be at least $5 \%$ by volume of the solids in the final mud mix [33]. This can be seconded by the findings by Alsabagh et al., [26] who found the use of $6 \%$ cellulosic fiber produced the best performance in combatting lost circulation. They also observed that $6 \%$ of fine peanut hulls were able to reduce spurt loss from $120 \mathrm{ml}$ to $24 \mathrm{ml}$. According to [34], mud invasion increased as the concentration of LCM depleted. As such, the concentration of LCM should be maintained properly in order to maintain the good seal. Several researchers have also observed similar trends. Increase amount of sized durian rind used from $0 \mathrm{~g}$ to $20 \mathrm{~g}$ had reduced the mud losses from $3500 \mathrm{ml}$ to $2600 \mathrm{ml}$ [35]. The increase amount of fiber used from $10 \mathrm{~g}$ to $30 \mathrm{~g}$ had reduced the spurt loss of four samples from $3 \mathrm{ml}$ to $0 \mathrm{ml}$ [7]. The increasing amount of associative polymer NIF from $0 \mathrm{~g}$ to $10 \mathrm{~g}$ reduced the total mud invasion to $0.5 \mathrm{~cm}[23]$. 


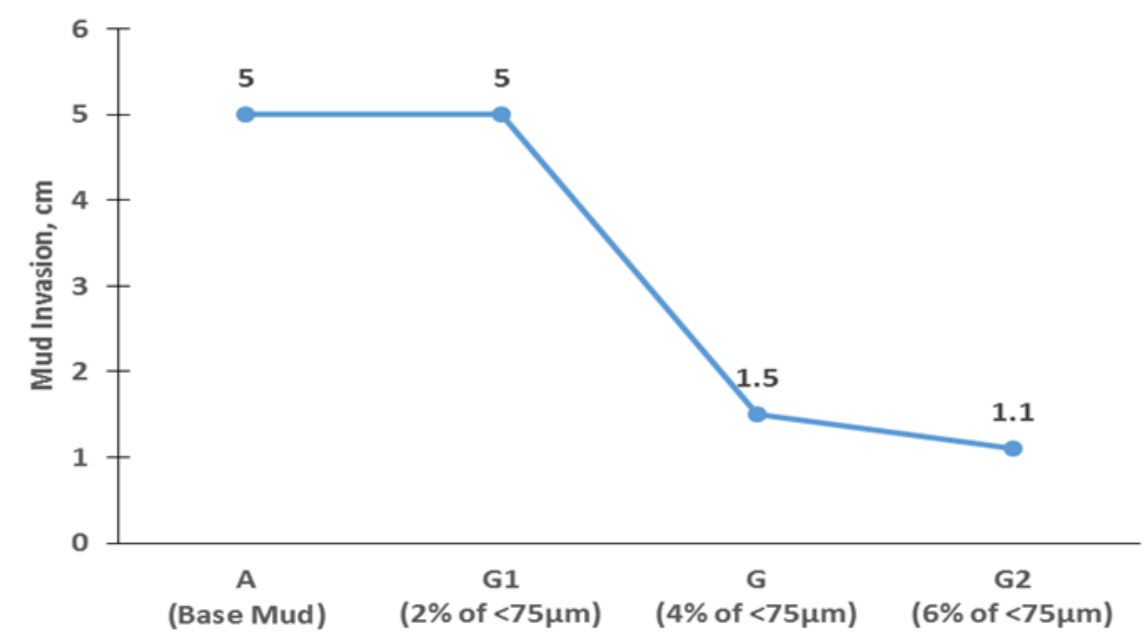

Fig. 7. Effect of different concentration of OPT fiber to mud invasion

\section{Conclusions}

The conclusion that can be drawn from this study is the Oil Palm Trunk (OPT) fiber could be used as either FLC or LCM. However, the LCM performance is better than FLC. Further treatment is needed if it is to be used as FLC. The lowest fluid loss of $5.2 \mathrm{ml}$ could be observed for the smallest sizes of OPT fiber $(<75 \mu \mathrm{m})$. As for the LCM, the OPT fiber range from 75 to $150 \mu \mathrm{m}$ is the most suitable size for 20/40 sand bed. The addition of different concentration of OPT fiber shows that at least $6 \%$ concentration is needed to reduce mud invasion.

\section{Acknowledgement}

This work was supported by Faculty of Chemical Engineering- Universiti Teknologi MARA (UiTM) and FRGS research grant (RMI File No. 600-IRMI/FRGS 5/3 (104/2017). The authors would like to thank Forest Research Institute Malaysia (FRIM) and Scomi Oiltools Sdn Bhd for providing materials for this study.

\section{References}

[1] Ghazali, Nurul Aimi, Nur Hashimah Alias, T. A. T. Mohd, S. I. Adeib, and M. Y. Noorsuhana. "Potential of corn starch as fluid loss control agent in drilling mud." In Applied Mechanics and Materials, vol. 754, pp. 682-687. Trans Tech Publications Ltd, 2015. https://doi.org/10.4028/www.scientific.net/AMM.754-755.682

[2] Navarrete, R. C., R. E. Himes, and J. M. Seheult. "Applications of xanthan gum in fluid-loss control and related formation damage." In SPE Permian Basin Oil and Gas Recovery Conference. Society of Petroleum Engineers, 2000. https://doi.org/10.2118/59535-MS

[3] Caenn, Ryen, Henry CH Darley, and George R. Gray. Composition and properties of drilling and completion fluids. Gulf professional publishing, 2011.

[4] Sauki, Arina, Nur 'Izzati Hasan, Fardelen Binti Md Naimi, and Nur Hidayati Othman. "Development of environmental friendly lost circulation material from banana peel." In AIP Conference Proceedings, vol. 1901, no. 1, p. 130016. AIP Publishing LLC, 2017. https://doi.org/10.1063/1.5010576

[5] Majid, Nor Fatihah Abdul, Issham Ismail, and Mohd Fauzi Hamid. "Using durian rind as bridging material to overcome fluid loss and lost circulation problems in drilling operations." Jurnal Teknologi 78, no. 8 (2016). https://doi.org/10.11113/it.v78.7563

[6] Azizi, Azlinda, Arina Sauki, Nurul Almi Ghazali, Nurul Hidayah Imam, Siti Khatijah Jamaludin, and Tengku Amran Tengku Mohd. "Effective bridging agent particle sizes of reservoir drilling mud." In Applied Mechanics and Materials, vol. 548, pp. 1871-1875. Trans Tech Publications Ltd, 2014. 
https://doi.org/10.4028/www.scientific.net/AMM.548-549.1871

[7] Ramasamy, Jothibasu, and Md Amanullah. "Novel fibrous lost circulation materials derived from deceased date tree waste." In SPE Kingdom of Saudi Arabia Annual Technical Symposium and Exhibition. Society of Petroleum Engineers, 2017. https://doi.org/10.2118/187989-MS

[8] Ghazali, Nurul Aimi, M. Y. M. Yusof, A. Azizi, T. A. T. Mohd, N. Alias, A. Sauki, and E. Yahya. "Lost Circulation Material Characteristics of Apple Skin Powder in Drilling Mud." In Advanced Materials Research, vol. 1119, pp. 564-568. Trans Tech Publications Ltd, 2015.

https://doi.org/10.4028/www.scientific.net/AMR.1119.564

[9] Okon, Anietie N., Francis D. Udoh, and Perpetua G. Bassey. "Evaluation of rice husk as fluid loss control additive in water-based drilling mud." In SPE Nigeria Annual International Conference and Exhibition. Society of Petroleum Engineers, 2014. https://doi.org/10.2118/172379-MS

[10] Azizi, Azlinda, Mohd Shahrul Nizam Ibrahim, Ku Halim Ku Hamid, Arina Sauki, Nurul Aimi Ghazali, and Tengku Amran Tengku Mohd. "Agarwood waste as a new fluid loss control agent in water-based drilling fluid." International Journal of Science and Engineering 5, no. 2 (2013): 101-105. https://doi.org/10.12777/ijse.5.2.101-105

[11] Fidan, E., T. Babadagli, and E. Kuru. "Use of cement as lost circulation material-field case studies." In IADC/SPE Asia Pacific Drilling Technology Conference and Exhibition. Society of Petroleum Engineers, 2004. https://doi.org/10.2118/88005-MS

[12] Lavrov, Alexandre. Lost circulation: mechanisms and solutions. Gulf Professional Publishing, 2016.

[13] Alam, Md Zahangir, Abdullah A. Mamun, Isam Y. Qudsieh, Suleyman A. Muyibi, Hamzah M. Salleh, and Nor Marina Omar. "Solid state bioconversion of oil palm empty fruit bunches for cellulase enzyme production using a rotary drum bioreactor." Biochemical Engineering Journal 46, no. 1 (2009): 61-64.

https://doi.org/10.1016/j.bej.2009.03.010

[14] Maniruzzaman, AA Md, A. W. Hamadb, A. M. Malekac, and M. Elserganyd. "Rheological properties of cellulose oil palm fiber (COPF) modified 80-100 asphalt binder." J Adv Res Appl Mech 7, no. 1 (2015): 21-30.

[15] Aljuboori, Ahmad H. Rajab. "Oil palm biomass residue in Malaysia: availability and sustainability." International Journal of biomass \& renewables 2, no. 1 (2013): 13-18.

[16] Dungani, Rudi, Mohammad Jawaid, HPS Abdul Khalil, Jasni Jasni, Sri Aprilia, Khalid Rehman Hakeem, Sri Hartati, and M. N. Islam. "A review on quality enhancement of oil palm trunk waste by resin impregnation: Future materials." BioResources 8, no. 2 (2013): 3136-3156. https://doi.org/10.15376/biores.8.2.3136-3156

[17] Chen, Hongzhang. "Biotechnology of lignocellulose." Theory and Practice. China: Chemical Industry Press and Springer (2014).

[18] RP, API. "Recommended Practice for Field Testing Water-based Drilling Fluids." (2009): 8-10.

[19] Khan, Mansoor Ali, H. S. Al-Saliml, and Leila Niloofar Arsanjani. "Development of high temperature high pressure (HTHP) water based drilling mud using synthetic polymers, and nanoparticles." Journal of Advanced Research in Fluid Mechanics and Thermal Sciences 45, no. 1 (2018): 99-108.

[20] Wilfred, Okologume C., and Akinwumi E. Akinade. "Comparative study of basic properties of mud prepared with nigerian local clay and mud prepared with foreign clay: A case study of abbi clay deposit." International Journal of Engineering and Technologies 8 (2016): 61-71.

https://doi.org/10.15376/biores.8.2.3136-3156

[21] Mihalakis, Th S., P. Makri, V. C. Kelessidis, G. Christidis, A. Foscolos, and K. Papanikolaou. "Improving rheological and filtration properties of drilling muds with addition of greek lignite." In 7th National Congress on Soil Mechanics, pp. 24-26. 2004.

[22] I. OFI Testing Equipment. "Filter Press With CO 2 Assembly." Instr. Man., no. 2.5, pp. 0-18, 2014.

[23] Reid, P., H. Santos, F. Labenski, F. Sabins, and L. Watters. "Associative polymers for invasion control in water-and oil-based muds and in cementing spacers: laboratory and field case histories." In American Association of Drilling Engineers, AADE-04-DF-HO-33, prepared for presentation at the AADE 2004 Drilling Fluids Conference. 2004.

[24] Brookey, Tommy F. "Aphron-containing well drilling and servicing fluids." U.S. Patent 5,881,826, issued March 16, 1999.

[25] Collins, Natalia, Donald Whitfill, Andrei Kharitonov, and Matthew Miller. "Comprehensive approach to severe loss circulation problems in Russia." In SPE Russian Oil and Gas Conference and Exhibition. Society of Petroleum Engineers, 2010. https://doi.org/10.2118/135704-MS

[26] Alsabagh, Ahmed Mohamed, Mahmoud Ibrahim Abdou, Hany El-sayed Ahmed, Ahmed Abdel-salam Khalil, and 
Amany Ayman Aboulrous. "Evaluation of some natural water-insoluble cellulosic material as lost circulation control additives in water-based drilling fluid." Egyptian journal of petroleum 24, no. 4 (2015): 461-468.

https://doi.org/10.1016/i.ejpe.2015.06.004

[27] I. OFI Testing Equipment, "140-30 - API Bench-Mount Filter Press, with CO2 Pressuring Assembly - Instruction Manual." 2014.

[28] N. F. A. Majid, I. Ismail, and M. F. Hamid, Jurnal Teknologi Science and Engineering, Elektronische Ressource., vol. 78, no. 8. Penerbit UTM Press, 2016.

[29] Ghazali, Nurul Aimi, Tengku Amran Tengku Mohd, Nur Hashimah Alias, Azlinda Azizi, and Ahmad Azwan Harun. The effect of lemongrass as lost circulation material (LCM) to the filtrate and filter cake formation. Vol. 594. Trans Tech Publications Ltd, 2014. https://doi.org/10.4028/www.scientific.net/KEM.594-595.68

[30] Chen, Hongzhang. "Biotechnology of lignocellulose." Theory and Practice. China: Chemical Industry Press and Springer (2014).

[31] Asunción, Josep. The complete book of papermaking. Lark Books, 2003.

[32] Rowell, Roger M. "Characterization and factors effecting fiber properties." Natural polymers and agrofibers based composites (2000).

[33] Abrams, Albert. "Mud design to minimize rock impairment due to particle invasion." Journal of petroleum technology 29, no. 05 (1977): 586-592.

https://doi.org/10.2118/5713-PA

[34] Reid, Paul Ian, and Helio Santos. "Ultra-low Invasion Drilling Fluids: A Practical Route to Reduced Wellbore Instability, Reduced Mud Losses, Wellbore Strengthening and Improved Well Productivity." In SPE/IADC Indian Drilling Technology Conference and Exhibition. Society of Petroleum Engineers, 2006. https://doi.org/10.2118/101329-MS

[35] I. Ismail, A. B. M. Nor, M. F. Hamid, and A. R. Ismail, Jurnal Teknologi Science and Engineering, Elektronische Ressource., vol. 74, no. 1. Penerbit UTM Press, 2015.

https://doi.org/10.11113/it.v74.3323 